\title{
$\mathrm{Ni}$ 基鋳造合金の疲労強度に及ぼす 平均応力および鋳造欠陷の影響十
}

\author{
藤井 達也* 蓮沼 将太** 小川 武史 ${ }^{* *}$ \\ 禹 明勳*** 高梨 正祐****
}

\section{Effect of Mean Stress and Casting Defect on Fatigue Strength of Ni Based Castalloys}

\author{
by \\ Tatsuya FumI*, Shota Hasunuma**, Takeshi Ogawa**, \\ Myunghun Woo*** and Masahiro TAKANASHI****
}

\begin{abstract}
The purpose of this study is to evaluate the effect of mean stress and casting defect on fatigue strength of Ni based castalloys, 246 and 100, using ultrasonic fatigue tests, which were conducted under stress ratios, $R=-1,0$ and 0.3 , at a cyclic frequency of $20 \mathrm{kHz}$. The results revealed that fatigue strength decreased by subjecting mean stress. SEM observation for the 246 and 100 alloys near the fracture origin exhibited that cracks initiated from a casting defect near the specimen surface for the majority of the specimens, where a flat fracture surface was formed in the vicinity of the defects. Also conducted were ultrasonic fatigue tests for shot-peened specimens under $R=0$ in order to change the location of the fracture origin. The results indicated that the influence of the casting defect near the specimen surface became negligible in the very high cycle fatigue regime. Stress intensity factor range for the casting defect, $\Delta K_{\mathrm{CD}}$, which was calculated by the axial projected area of the defect and the stress range, correlated with the fatigue life, $N_{\mathrm{f}}$. The influence of mean stress and the casting defect was evaluated by the relationship between $N_{\mathrm{f}}$ and the equivalent stress intensity factor range, $\Delta K_{\text {eq }}$, calculated by taking account of mean stress. The result suggested that the effect of casting defect could be expressed uniformly by the evaluation of $\Delta K_{\mathrm{eq}}-N_{\mathrm{f}}$ relationship.
\end{abstract}

\section{Key words:}

Fatigue strength, Mean stress, Casting defect, Fracture origin, Ultrasonic fatigue test, Giga-cycle fatigue, Ni based castalloy

\section{1 緒言}

航空機エンジンやターボチャージャーのタービンは, その性能向上のために高温化と複雑形状化が求められて いる. そのため, タービン翼は精密鋳造を用いて生産され, タービン翼の材料には耐熱性に優れた高強度材である $\mathrm{Ni}$ 基鋳造合金が用いられる. タービンは回転速度の変動に 伴う繰返し遠心応力に重畳して，運転中の振動による繰 返し応力を受けるので, 疲労き裂が発生, 進展することに より, 疲労破壊に至る可能性を考慮する必要がある.すな わち, タービン材料である $\mathrm{Ni}$ 基鋳造合金について, 適切 に疲労強度を評価することが重要となる。

小林らは熱間等方加圧法（HIP）処理を施した Ni 基鋳 造合金と鋳造まま（As-cast）の同材料に対して，高温高サ イクル疲労試験を行った ${ }^{1)}$. その結果, 低サイクル疲労域 では表面起点型破壊を生じ，HIP 処理材とAs-cast 材の疲 労寿命の差はほとんどなかった。一方, 高サイクル疲労域
で As-cast 材は内部起点型破壊となり, HIP 処理材より短 寿命となった. 著者らの別報においても, 倉光らは Ni 基 鋳造合金に対して疲労試験を行い, 高応力域では表面起 点型破壊を生じるが，低応力域では破壊起点が試験片内 部の鋳造欠陥となることを示した ${ }^{2)}$. 一方, 櫻井らは疲労 き裂進展試験を行い, 下限界応力拡大係数範囲 $\Delta K_{\text {th }}$ を評価 した ${ }^{3)}$ 。ここで，超低速度の疲労き裂進展が観察されたこ とから, 超高サイクル域において, 鋳造欠陥を起点とした 疲労破壊に至ることが推測される.さらに, 疲労き裂進展 挙動は応力比に依存しているため, 疲労強度に平均応力 が影響すると考えられる。

そこで, 本研究では, 2 種類の $\mathrm{Ni}$ 基鋳造合金に対して, 平均応力付与が可能な超音波疲労試験機を用いた超高サ イクル疲労試験を行う。また，別報 3 に示された疲労き裂 進展特性との関係をもとに, 疲労強度に及ぼす平均応力 と鋳造欠陥の影響を検討する。

$\dagger$ 原稿受理 平成29年 4月20日 Received Apr. 20,2017@2017 The Society of Materials Science, Japan

* 学生会員 青山学院大学大学院 理工学研究科 干 252-5258 相模原市中央区淵野辺

Graduate School of Sci. and Eng., Aoyama Gakuin Univ., Chuoh-ku, Sagamihara 252-5258.

** 正会員 青山学院大学 理工学部 $\overline{7} 252-5258$ 相模原市中央区淵野辺

Dept. Mech. Engng., Aoyama Gakuin Univ., Chuoh-ku, Sagamihara 252-5258.

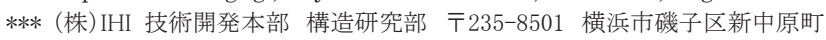

Research Laboratory, IHI Corp., Isogo-ku, Yokohama 235-8501.

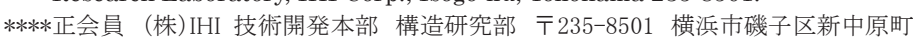

Research Laboratory, IHI Corp., Isogo-ku, Yokohama 235-8501. 


\section{2 試験片および実験方法}

\section{$2 \cdot 1$ 供試材および試験片}

供試材の $\mathrm{Ni}$ 基鋳造材 246 および 100 合金の化学成分 を Table 1 に示す。両合金は Co 添加により強度に優れ， 特に 246 合金にはW が添加されているため高温強度に も優れるといった特徵がある. Table 2 に両供試材の機械 的性質および密度を示す。ここで，密度はアルキメデス 法, ヤング率は後述する超音波疲労試験における試験片 の固有振動数を基に算出した值，その他は引張試験によ り得られた值である.

Fig. 1 に試験片の形状を示す．ほとんどの実験には(a) に示す試験片を用いたが，応力比 $R=0$ の 246 合金の実 験には(b)の形状を用いた。これらの試験片については, 軸方向の縦波により $20 \mathrm{kHz}$ で共振するように寸法調整が 施されている。また，試験片中央部にはエメリ一紙を用 いて\#2000まで軸方向に研磨を施した。

\section{$2 \cdot 2$ 実験方法}

平均応力の負荷が可能な自作の超音波疲労試験機では, ピエゾアクチュエータにより $20 \mathrm{kHz}$ の繰返し応力を，第 一電気(株)のハイブリッドアクチュエータにより平均応 力を負荷した. ピエゾアクチュエータには BRANSON 社 製の超音波溶着機 CT-20 を用いた. 実験は, 応力比 $R=-1$, 0 および 0.3 で応力範囲 $\Delta \sigma$ 一定の繰返し負荷を, 室温大気 中（温度 $23 \sim 25^{\circ} \mathrm{C}$, 湿度 $20 \sim 55 \%$ ） において負荷し, 繰 返し数 $N=1.0 \times 10^{9}$ 回を打切り繰返し数とした. なお, 試

Table 1 Chemical composition (mass $\%$ )

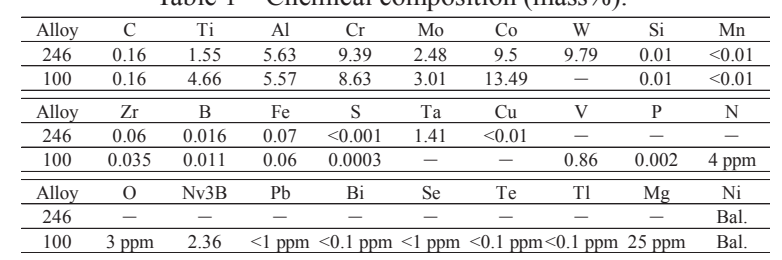

Table 2 Mechanical properties and density.

\begin{tabular}{cccc}
\hline Alloy & Young's modulus [GPa] & $0.2 \%$ proof stress [MPa] & Tensile strength [MPa] \\
\hline 246 & 212.6 & 860 & 940 \\
\hline 100 & 179.7 & 763 & 892 \\
\hline \hline Alloy & Elongation [\%] & Reduction of area [\%] & Density $\left[\mathrm{g} / \mathrm{cm}^{3}\right]$ \\
\hline 246 & 10.8 & - & 8.44 \\
\hline 100 & 8.8 & 12.1 & 7.85 \\
\hline
\end{tabular}
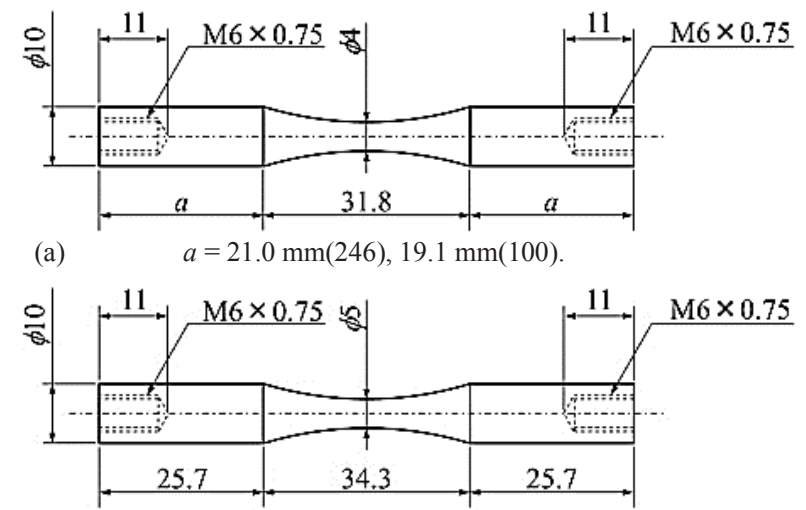

(b)

Fig. 1 Shape of ultrasonic fatigue specimens for most of the tests (a) except for alloy 246 at $R=0$ (b).
験中は高速の繰返し負荷に伴う試験片中央部の温度上昇 抑制のため, 間欠運転を行うとともに，強制空冷を行った。

\section{$3 \cdot 1$ 平均応力の影響}

\section{3 実験結果および考察}

Fig. 2 に縦軸を応力範囲 $\Delta \sigma$, 横軸を破断繰返し数 $N_{\mathrm{f}}$ と した $S-N$ 曲線を示す。同図に中空印で示したショットピ 一ニング処理 $(\mathrm{SP})$ 材については, 後述の $3 \cdot 3$ 節におい て示す． $S-N$ 曲線のばらつきは大きいが，246 合金と 100 合金の疲労強度に差異はほとんど見られなかった。一方, 平均応力の負荷による疲労強度の低下が確認されたので, 次式に示すスミス・ワトソン・トッパー（SWT）法4)を用 いて平均応力補正を行った.

$$
\Delta \sigma_{\text {eq }}=2 \cdot \sigma_{\text {max }}^{1 / 2} \cdot(\Delta \sigma / 2)^{1 / 2}
$$

ここで, $\Delta \sigma_{\mathrm{eq}}$ は等価応力範囲, $\sigma_{\max }$ は最大応力である. 平 均応力補正した $S-N$ 曲線を Fig. 3 に示す. この結果から, $N_{\mathrm{f}}<10^{8}$ 回の寿命域では補正した $S-N$ 曲線は $R$ によらず, ほぼ一致する傾向を示した。しかし， $N_{\mathrm{f}}>10^{8}$ 回の寿命域 では $S-N$ 曲線のばらつきが大きく, 平均応力以外にも疲 労強度に強く影響を及ぼす因子があることが推測できる. 以下では，その因子について検討する.

\section{$3 \cdot 2$ 破壊起点の観察}

破面観察を走査型電子顕微鏡（SEM）によって行った 結果，破壊起点は試験片表面近傍内部の鋳造欠陥である

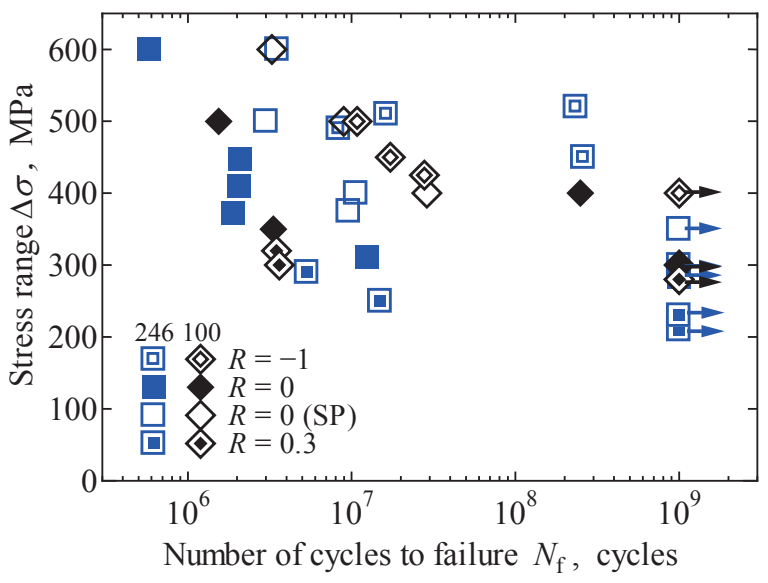

Fig. $2 S$ - $N$ curve for Ni based castalloys.

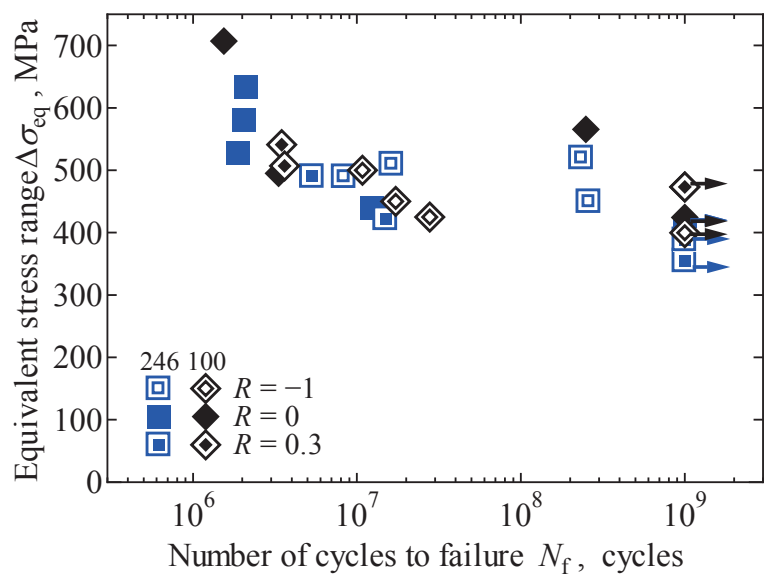

Fig. 3 Modified $S$ - $N$ curve for Ni based castalloys. 
ことがわかった。Fig. 4 および 5 に，それぞれ 246 合金 および 100 合金において破壊起点となった鋳造欠陥の例 を示す。ここで， $N=10^{9}$ 回で未破壊となった試験片につ いては， $R=0, \Delta \sigma=500 \mathrm{MPa}$ の条件で繰返し負荷をする ことで鋳造欠陥を露出させた．Fig. 2 に示した大部分の 試験片において，起点部には類似した鋳造欠陥が観察さ れた。また，破壊起点の周辺には比較的平坦な破面が形 成されていた。一部の試験片では Fig. 4(a), (b)および(d) のような面の向きが異なった平坦破面からなる凹凸に 富んだ破面が観察された。

破壊起点となった鋳造欠陥は，試験片の表面近傍で観 察されることが多いことから，鋳造欠陥の位置を試験片 表面からの距離として測定した。 Fig. 6 に測定結果を示 す。図中のエラーバーは, 試験片表面から鋳造欠陥まで の最短距離および最長距離の範囲である。なお，一部の 条件では，き裂が分岐したことにより破面上の破壊起点 を観察できなかったため，Fig. 2 に比べてデータが少な い。また，SP 材の結果については，後述の $3 \cdot 3$ 節にお いて示す. Fig. 6 から, 破壊起点となる鋳造欠陥の位置 は，試験片表面近傍となる傾向がある。特に， $R=0$ およ び 0.3 の場合には，ほとんどの破壊起点が表面から 100 $\mu \mathrm{m}$ 以内となっている. $R=-1$ の場合には表面から $200 \sim$ $500 \mu \mathrm{m}$ の破壊起点も見られるが， $\Delta \sigma=500 \mathrm{MPa}$ では表
面から $100 \mu \mathrm{m}$ 以内となっており，やはり表面近傍が破 壊起点となる傾向が認められる。この原因として, 内部 き裂における応力拡大係数 $K$ は, 試験片表面近傍のほう が大きくなるという結果が西谷らにより示されている ${ }^{5)}$. すなわち，試験片表面近傍のき裂進展駆動力が内部より 大きくなるため, 試験片表面近傍の鋳造欠陥が破壊起点 になる傾向があると考えられる，なお，鋳造欠陥寸法の ばらつきが大きい場合にはこのような傾向は見られず, 最大の鋳造欠陥が破壊起点となる.

本研究において, 表面近傍の鋳造欠陥が破壊起点とな る傾向を示すことは，比較的寸法ばらつきの小さい鋳造 欠陥が材料全体に分布していることを示唆している。こ こで, 破壊起点となる鋳造欠陥寸法について, 鋳造欠陥 の軸方向投影面積 area を測定し, 代表寸法として $\sqrt{\text { area }}$ を Fig. 7 に示す. なお, 中空印で示したショットピーニ ング処理材の結果は, 後述の $3 \cdot 3$ 節において示す.ここ で，鋳造欠陥寸法を測定する際は，投影面上の隣接する 欠陥は，隣接するそれぞれの欠陥の長さおよび深さの最 大值の半分よりも久陷間の距離が短い場合，単一の欠陥 として扱った ${ }^{6}$. Fig. 4, Fig. 5 および後述する Fig. 9 中 には，単一の欠陥として扱った鋳造欠陥を点線で示して おり, 破線の内側の面積から $\sqrt{\text { area }}$ を求めた. Fig. 7 から, 破壊起点となる鋳造欠陥の $\sqrt{\text { area }}$ と $\Delta \sigma の$ 相関は見られな

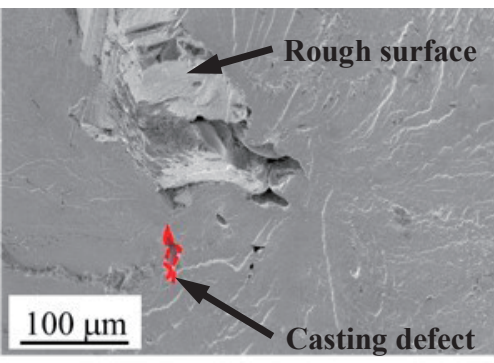

(a) $R=-1, \Delta \sigma=520 \mathrm{MPa}$
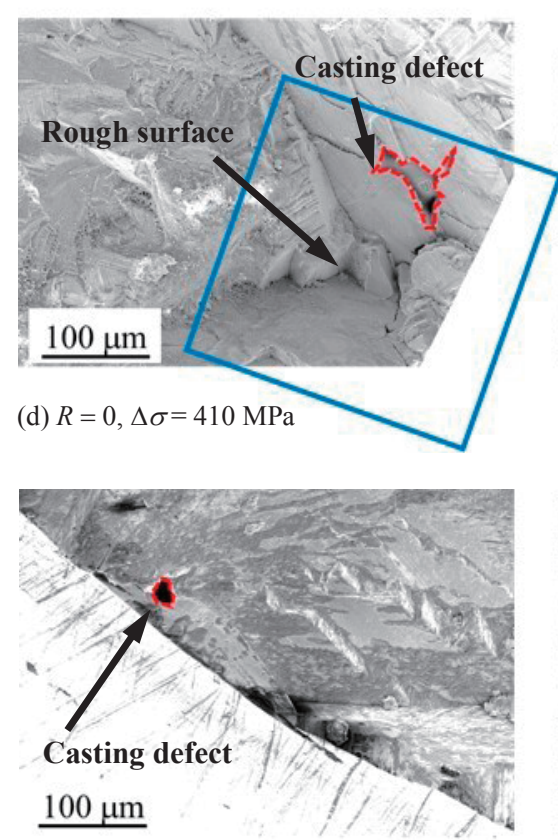

(a) $R=-1, \Delta \sigma=500 \mathrm{MPa}$

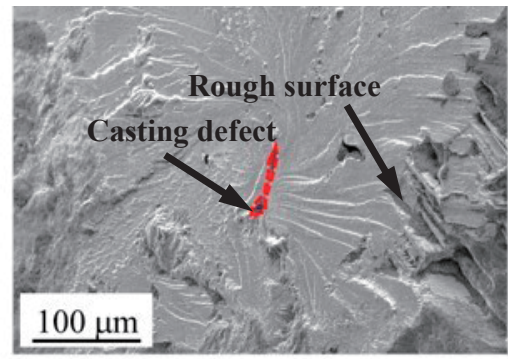

(b) $R=-1, \Delta \sigma=510 \mathrm{MPa}$

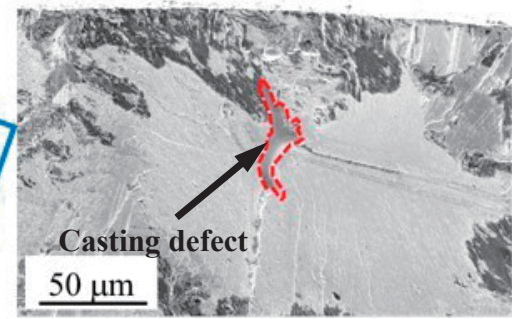

(e) $R=0.3, \Delta \sigma=230 \mathrm{MPa}$

Fig. 4 Fracture origins of alloy 246.

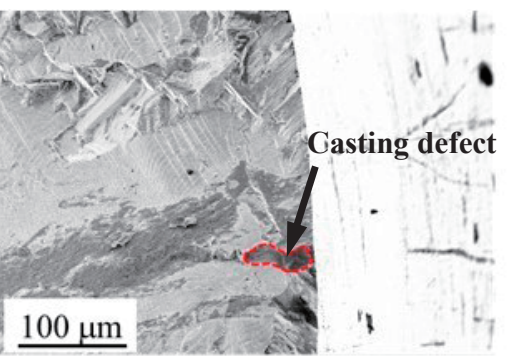

(b) $R=0, \Delta \sigma=400 \mathrm{MPa}$

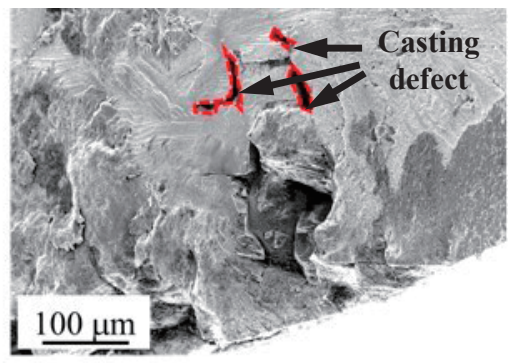

(c) $R=-1, \Delta \sigma=450 \mathrm{MPa}$

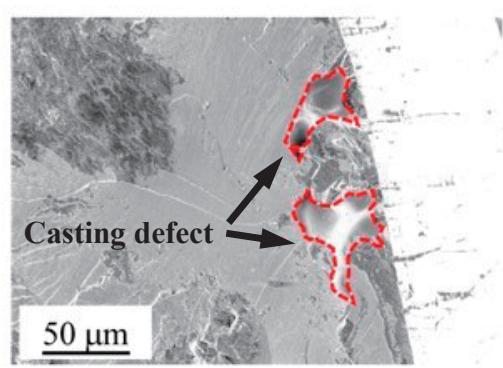

(f) $R=0.3, \Delta \sigma=210 \mathrm{MPa}$

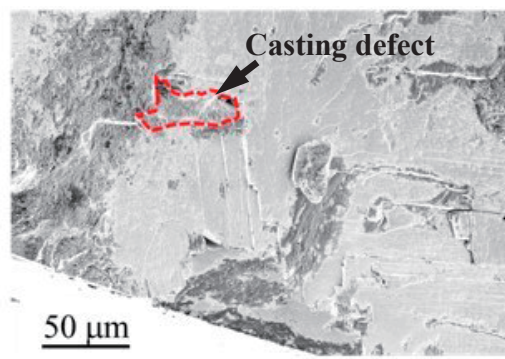

(c) $R=0.3, \Delta \sigma=320 \mathrm{MPa}$

Fig. 5 Fracture origins of alloy 100 . 
W.

鋳造欠陥の周辺に観察される平坦破面について, 形成 機構を解明するため, 電子線後方散乱回折 (EBSD) 法を 用いて結晶方位解析を行った。この結果は別報 2)に示し ているが，246 合金に観察された大きな平坦破面は，結 晶粒内の $\left\{\begin{array}{llll}1 & 1 & 1\end{array}\right\}$ 面に沿って形成されていた。一方，一部 の破面には Fig. 4(d)のように面の向きが異なった平坦破 面からなる凹凸に富んだ破面様相が見られた。この破面 の形成機構を検討するため, Fig. 4(d)の四角枠で囲んだ 箇所について, 3 次元観察を行った. Fig. 8(a)に観察位置 の SEM 写真, Fig. 8(b)にレーザー顕微鏡観察から得られ た破面の鳥瞰図を示す. Fig. 8(a)において，点線で囲った 破面 Area A と Area B がな寸角を Fig. 8(b)に示した高さ 分布をもとに各 Area の仰角を測定し, 2 平面のなす角を 計算した結果，両破面のなす角は 67.4 ○であった. $\left\{\begin{array}{lll}1 & 1 & 1\end{array}\right\}$

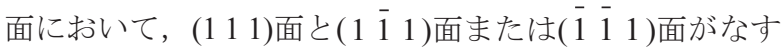
角は 70.5 ○である。したがって，これら 2 つのなす角が 概ね一致していることから, Area A と Area B は同一結 晶粒内の $\left\{\begin{array}{llll}1 & 1 & 1\end{array}\right\}$ 面で形成された破面であると考えられる。 すなわち，破壊起点近傍の凹凹に富んだ破面は，平坦破 面が屈曲を繰返すことで形成される破面であり，本質的 には平坦破面と同等の破壊機構である。このような平坦 破面形成機構に関する検討は, き裂進展に関する別報に おいても行われている3).

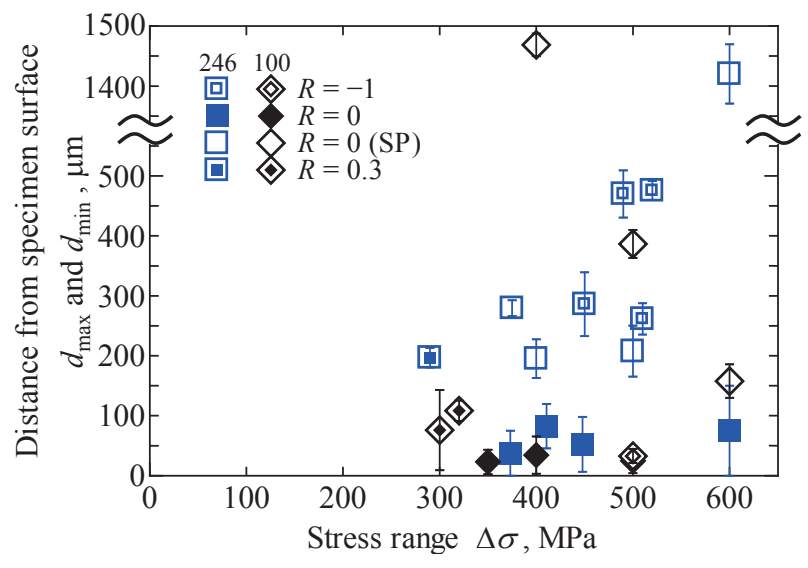

Fig. 6 Position of casting defect.

\section{$3 \cdot 3$ ショットピーニング処理材に対する疲労試験}

Fig. 6 に示したように，246および 100 合金ともに試験 片表面近傍に存在寸る鋳造欠陥を破壊起点とした内部起 点型破壊を生じた。この原因は, 表面近傍の欠陥のわずか な $K$ の増大によると考えた.このことを確認するために, ショットピーニング $(\mathrm{SP})$ 処理を用いて破壊起点を内部に 限定した状態で疲労試験を行い, その $S-N$ 曲線と破壊起 点から上記の考察について検討した. SP 処理にはガラス ビーズを用い, SP 処理条件は加工圧 $0.3 \mathrm{MPa}$, カバレージ $100 \%$ とした。 また, SP 処理後の算術平均粗さ $R a$ は 0.65 $\sim 0.9 \mu \mathrm{m}$ であり, 表面が破壊起点になることのない程度で ある. また, 類似した Ni 基鋳造材 $713 \mathrm{C}$ 合金の $\mathrm{SP}$ 材の断 面において, 押込み力 $0.49 \mathrm{mN}$ でビッカース硬さ試験を 行った結果, 表面から $100 \mu \mathrm{m}$ 程度まで SP 処理による硬 化が認められた。この結果を考慮して, Fig. 6 において表 面から $100 \mu \mathrm{m}$ 以内の破壊起点が多く見られた $R=0$ で実 験を行った.

246 および 100 合金の SP 材において，破壊起点となっ た鋳造欠陥の例を Fig. 9 に示す. Fig. 4 および Fig. 5 と同 様に, 破壊起点付近には平坦な破面が形成されている. Fig. 6 に示したように, SP 処理により表面から $100 \mu \mathrm{m}$ 以内で の破壊が抑制され, 破壊起点が内部に移っている. SP 処 理を行うと, 上記の硬さの増大に加えて平均応力の影響 に置き換えられる圧縮残留応力が発生し, き裂進展寿命

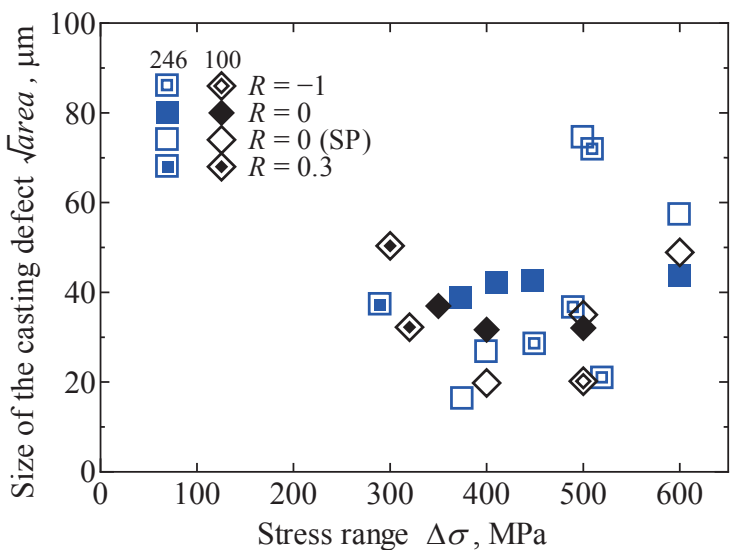

Fig. 7 Size of casting defect.

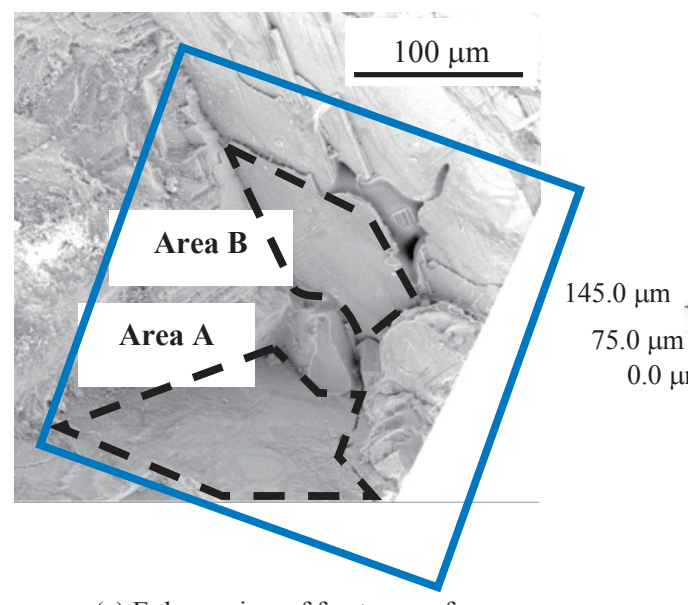

(a) Enlarge view of fracture surface

Fig. 8 Observation of fracture surface shown in Fig.4(d). 
を増大させると考えられる ${ }^{9)}$. しかし，粗大な結晶粒であ る本供試材では，その測定が困難である．Fig. 7 に示され ているように，ばらつきは大きいが，SP 材の破壊起点の 久陥は他の場合と同程度の $\sqrt{\text { area }}$ となっており, Fig. 2 で 確認できる SP 材の $N_{\mathrm{f}}$ の増大は，SP 処理による破壊起点 の移動に加えて，圧縮残留応力によるき裂進展寿命の増 大によるものと考えられる.

\section{$3 \cdot 4$ 疲労強度の支配因子}

Fig. 7 に示した鋳造欠陥の $\sqrt{\text { area }}$ と $\Delta$ を用いて, 応力拡 大係数範囲 $\Delta K_{\mathrm{CD}}$ を求めた.

$$
\Delta K_{\mathrm{CD}}=F \Delta \sigma \sqrt{\pi \sqrt{\text { area }}}
$$

ここで, 補正係数 $F$ は，鋳造欠陥が試験片内部の場合に 0.5 , 表面に接していた場合に 0.65 とした ${ }^{7)} . \Delta K_{\mathrm{CD}}$ と $N_{\mathrm{f}}$ の関係を Fig. 10 に示す. 同様な鋳造欠陥寸法と疲労強度 の検討は，林らによっても報告されている ${ }^{8)}$ 。 それぞれ の $R$ に対する $\Delta K_{\mathrm{CD}}-N_{\mathrm{f}}$ 関係は，右下がりの傾向となっ ており，Rが高いほど低 $\Delta K_{\mathrm{CD}}$ 側の結果となっている。そ
こで, $\Delta K_{\mathrm{CD}}-N_{\mathrm{f}}$ 関係に対して $S-N$ 曲線と同様な平均応力 の補正を試みた。 ウォーカー指数 $\gamma=0.5$ を用い, 次式に よって等価応力拡大係数範囲 $\Delta K_{\mathrm{eq}}{ }^{10)}$ を求めた.

$$
\Delta K_{\mathrm{eq}}=2 \cdot K_{\max }^{\gamma} \cdot\left(\Delta K_{\mathrm{CD}} / 2\right)^{1-\gamma}
$$

$\Delta K_{\mathrm{eq}}-N_{\mathrm{f}}$ 関係を Fig. 11 に示す. $R$ の影響はほとんど消 失しているが, $N_{\mathrm{f}}$ は < $10^{7}$ 回では $\mathrm{SP}$ 材の $N_{\mathrm{f}}$ が大きくなっ ている。一方，疲労限度における $\Delta K_{\mathrm{eq}}$ は，他の $\mathrm{SP}$ 材以外 の結果とほぼ一致している。したがって，SP 処理により 生じた破壞起点の移動および圧縮残留応力は, 疲労き裂 進展寿命を増大させるが， $10^{9}$ 回の超高サイクル域におい て評価した鋳造欠陥からのき裂発生および進展限界には， 影響を及ぼさないことがわかる。

Fig. 10 の $R=0.3$ では, 疲労限度において $\Delta K_{\mathrm{CD}}=1.4$ $\mathrm{MPa} \sqrt{\mathrm{m}}$ 程度であった。 著者らの別報 ${ }^{3)}$ において, 同じ $\mathrm{Ni}$ 基鋳造合金に対して行った疲労き裂進展試験から， $R>$ 0.9 の高応力比の下限界応力拡大係数範囲 $\Delta K_{\mathrm{th}}$ は, 結晶 方位等の微視組織条件によらず $1 \mathrm{MPa} \sqrt{\mathrm{m}}$ 程度であると

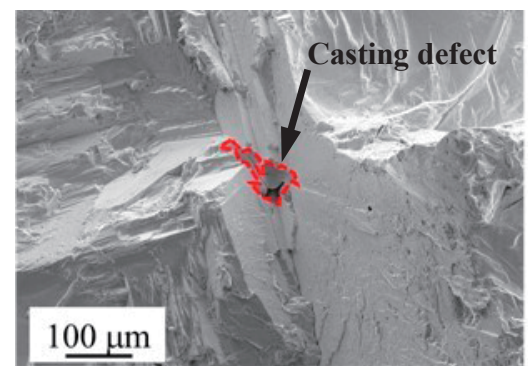

(a) Alloy $246(\mathrm{SP}), R=0, \Delta \sigma=600 \mathrm{MPa}$

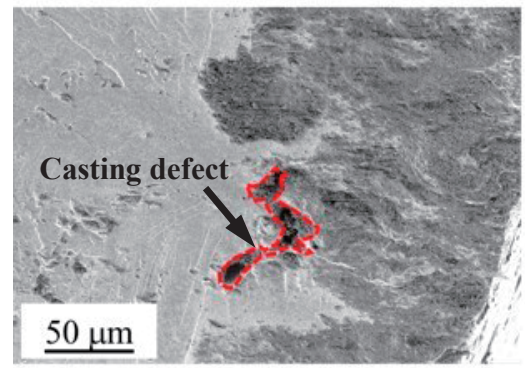

(d) Alloy 246(SP), $R=0, \Delta \sigma=300 \mathrm{MPa}$

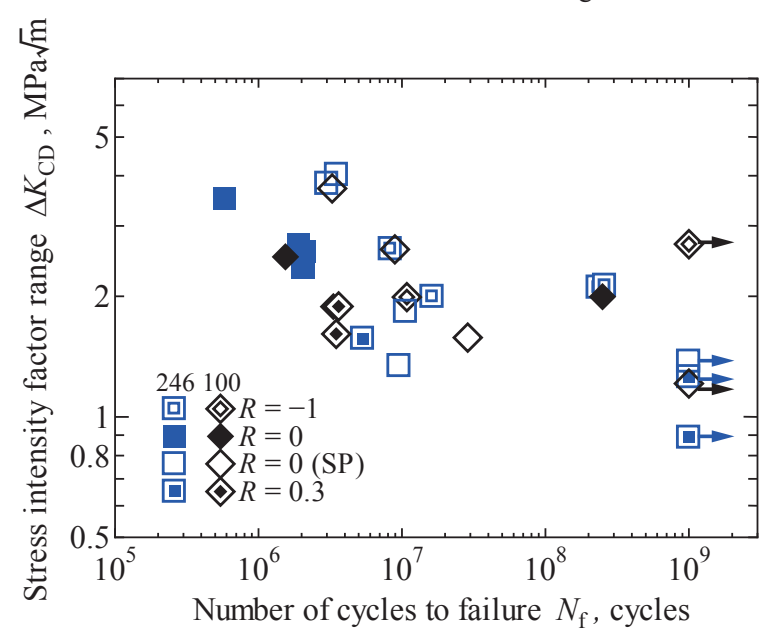

Fig. 10 Relationship between $\Delta K_{\mathrm{CD}}$ and $N_{\mathrm{f}}$

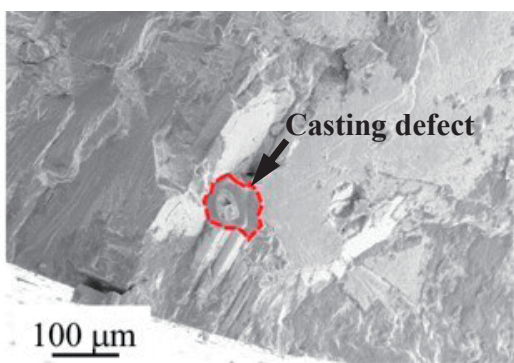

(b) Alloy $246(\mathrm{SP}), R=0, \Delta \sigma=500 \mathrm{MPa}$

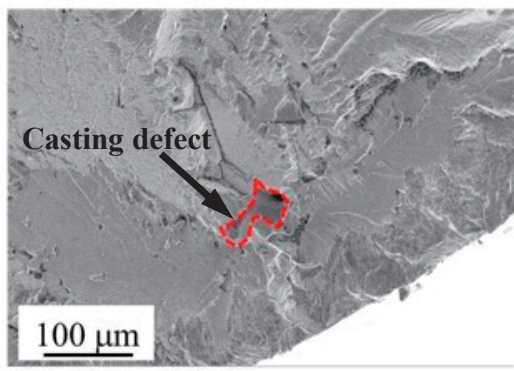

(e) Alloy $100(\mathrm{SP}), R=0, \Delta \sigma=600 \mathrm{MPa}$

ig. 9 Fracture origins of shot peened specimen.

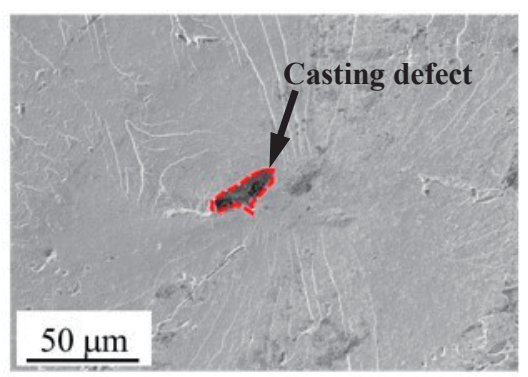

(c) Alloy $246(\mathrm{SP}), R=0, \Delta \sigma=375 \mathrm{MPa}$

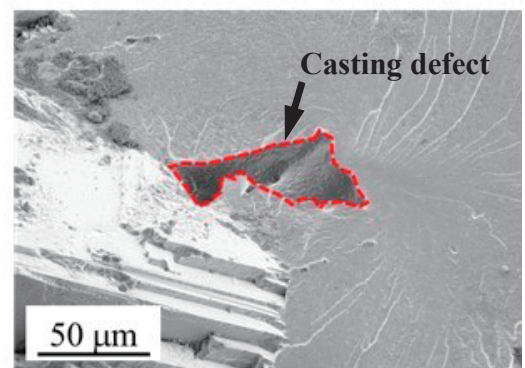

(f) Alloy $100(\mathrm{SP}), R=0, \Delta \sigma=500 \mathrm{MPa}$

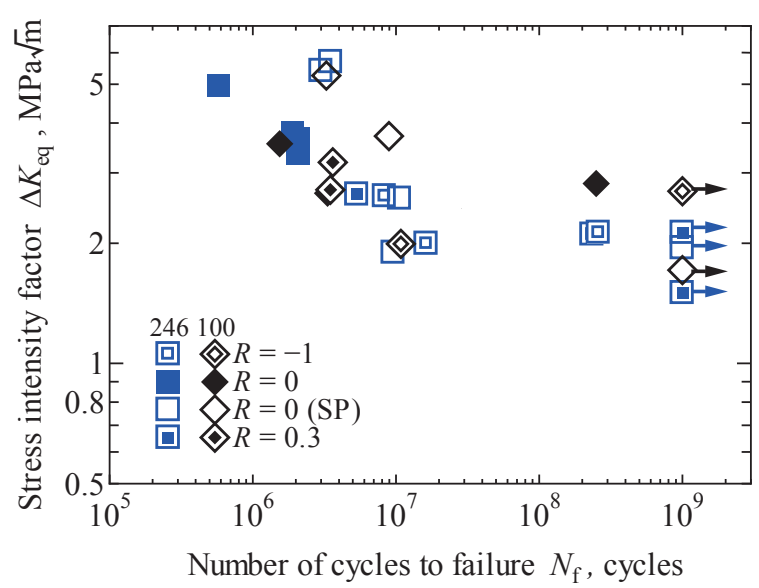

Fig. 11 Relationship between $K_{\text {eq }}$ and $N_{\mathrm{f}}$. 
いう結果が得られている. $R=0.3$ の疲労限度における $\Delta K_{\mathrm{CD}}$ は, $R=0.9$ の $\Delta K_{\mathrm{th}}$ よりも少し高い值となっている. 一方, $R=-1$ の疲労限度における $\Delta K_{\mathrm{CD}}$ は $2 \mathrm{MPa} \sqrt{\mathrm{m}}$ 程度 であり, $R=0.9$ の $\Delta K_{\text {th }}$ の約 2 倍となっている. すなわち, この $\Delta K_{\mathrm{CD}}$ の引張側の成分は, $R=0.9$ の $\Delta K_{\mathrm{th}}$ とほぼ一致 していることになる。これらの関係には，き裂開閉口挙 動が関与しており，厳密な一致に関する議論はできない が，疲労限度は鋳造欠陥から発生した微小き裂の進展限 界となっていると考えられる。

\section{4 結訔}

本研究では, $\mathrm{Ni}$ 基鋳造材 246 および 100 合金に対して, 平均応力負荷が可能な超音波疲労試験機を用い, $S-N$ 曲線 を評価した，得られた主な結果は以下の通りである。

1. 平均応力負荷の影響によって, 疲労強度が低下した。 また，大部分の試験片において，試験片表面近傍の 鋳造欠陥を起点とした内部起点型破壊を生じた。破 壊起点の周辺では $\left\{\begin{array}{lll}1 & 1 & 1\end{array}\right\}$ 面に沿ったき裂進展による 平坦破面が観察された。

2. ショットピーニング $(\mathrm{SP})$ 処理により表面近傍の破壊 起点を抑制して疲労試験を行った. SP 処理により破 壊起点が内部に移ったが，破壊起点の欠陥の寸法は SP 処理を行っていない場合と同程度であった。

3. 等価応力拡大係数範囲 $\Delta K_{\mathrm{eq}}$ と疲労寿命 $N_{\mathrm{f}}$ の関係を 求めた結果, SP 処理によりき裂進展寿命が増加する が， $10^{9}$ 回の疲労限度には影響を及ぼさない。

4. 破壊起点の欠陥寸法から求めた応力拡大係数範囲 $\Delta K_{\mathrm{CD}}$ について, 疲労限度における $\Delta K_{\mathrm{CD}}$ の引張側の 成分と別報 ${ }^{3)}$ に示された $R=0.9$ の $\Delta K_{\mathrm{th}}$ は，近い值を 示しており，疲労限度は鋳造欠陥から発生したき裂 の進展限界となっていると考えられる。

\section{参 考 文 献}

1) K. Kobayashi and M. Hayakawa, "High-temperature high-cycle fatigue properties of nickel based superalloy Alloy713C," Journal of High Pressure Institute of Japan, Vol.52, No.1, pp.24-29 (2014).

2) T. Kuramitsu, T. Fujii, S. Hasunuma, T. Ogawa and M. Woo and M. Takanashi, "Evaluation of pulsating tension fatigue strength and small crack growth behavior of $\mathrm{Ni}$ based castalloy 246," Proceeding of JSME conference, $¥ d a t a ¥ p d f ¥ J 0310102$.pdf, p.5 (2016-9).

3) K. Sakurai, S. Hasunuma, T. Ogawa, M. Woo and T. Masahiro, "Evaluation of fatigue crack growth threshold of cast Ni based superalloy by ultrasonic fatigue tests," pp.117-120, Proceeding of The $13^{\text {th }}$ Symposium on Fatigue, (2016-11).

4) Smith, K. N., Watson, P., and Topper, T. H., "A stress strain function for the fatigue of metals," Journal of Materials, Vol.5, No.4, pp.767-778 (1970).

5) H. Nishitani and Y. Murakami, "Stress intensity factors of semi-elliptical crack and elliptical crack : tension,"
Transactions of the Japan Society of Mechanical Engineers, Vol.40, No.329, pp.31-40 (1974).

6) H. Kobayashi, "Kouzoukenzensei handbook," pp.57-68 (2005) Kyoritsu Shuppan Co.

7) Y. Murakami, "Metal fatigue: effect of small defects and nonmetallic inclusions," pp.15-18 (1993) Yokendo LTD.

8) Y. Hayashi, H. Akebono, M. Kato and A. Sugeta, "Effect of material defect on fatigue strength of carbon steel casting SC49 for hydraulic turbine runner," Transactions of the Japan Society of Mechanical Engineers, Series A, Vol.76, No.768, pp.82-87 (2010-8).

9) H. Nishitani and M. Goto, "Effect of mean stress on crack initiation and initial crack propagation in axial fatigue of an annealed $0.45 \% \mathrm{C}$ steel", Transactions of the Japan Society of Mechanical Engineers, Series A, Vol. 50, No. 460, pp. 1926-1935 (1984).

10) J. L. de Almeida Ferreira, J. A. Araújo, P. Lima, T. M. Mourão and E. C. G. Menin, "Assessment of fatigue properties and S-N curves for DIN EN 10283 alloy steel," Proceeding of $18^{\text {th }}$ International Congress of Mechanical Engineering, (2005-11). 